\title{
Percent Predicted Inspiratory Reserve Volume
}

National Cancer Institute

\section{Source}

National Cancer Institute. Percent Predicted Inspiratory Reserve Volume. NCI Thesaurus. Code C112383.

The maximum volume of air a subject can inhale into the lungs after a tidal inhalation as a proportion of the predicted normal value. (CDISC) 